\title{
Inventory performance with pooling: Evidence from mergers and acquisitions
}

\author{
Nagihan Çömez-Dolgan ${ }^{\text {a,* }}$, Başak Tanyeri ${ }^{\mathrm{b}}$ \\ a School of Management and Administrative Sciences, Istanbul Sehir University, Altunizade, Istanbul 34662, Turkey \\ ${ }^{\mathrm{b}}$ Faculty of Business Administration, Bilkent University, Bilkent, Ankara 06800, Turkey
}

\section{A R T I C L E I N F O}

\section{Article history:}

Received 29 May 2014

Accepted 29 May 2015

Available online 11 June 2015

\section{Keywords:}

Finance

Mergers and acquisitions

Inventory pooling

Inventory turnover

Demand correlation

\begin{abstract}
A B S T R A C T
Theoretical studies show that compared to decentralized inventory management, (i) pooling inventories for different demand sources decreases the optimal safety stock, which in turn decreases inventory costs and (ii) the decrease in stock is related to the correlation between the different demand sources and variabilities of demands. Mergers and acquisitions (M\&A) provide a business context to investigate the effects of correlation and variability of the merging firms' demands on potential improvements in inventory performance through inventory pooling. While merging firms may not fully centralize their inventory decisions, the coordination of inventory and supply chain decisions may result in synergies. Using firm-level data for 270 same-industry mergers carried out in U.S. between 1981 and 2009, we find that the inventory turnover of bidder and target firms improves (relative to firms in their industry) following the successful completion of mergers. The improvement in turnover is especially pronounced in deals where the demand of bidder and target firms are negatively correlated prior to the merger. Our results provide novel empirical support for the predictions of theoretical models on inventory economies in $M \& A$.
\end{abstract}

(c) 2015 Elsevier B.V. All rights reserved.

\section{Introduction}

In 2013, merger activity reached $\$ 2.2$ trillion around the world (Bloomberg M\&A database), where our use of the term mergers refers to both mergers and acquisitions. In their surveys of merger studies, Jarrell et al. (1988), Andrade et al. (2001), Bruner (2004), Martynova and Renneboog (2008) and Betton et al. (2008) document that mergers are persistent across time, industries and countries. This paper empirically tests theoretical research in operations management on inventory pooling using M\&A as a research context in which the two merging firms may centralize inventory management for their previously separate demand sources.

Mergers may be motivated by the desire to increase shareholder value through: (i) increasing size and realizing economies of scale and scope (Ambrose and Megginson, 1992; Moeller et al., 2004; Fluck and Lynch, 1999); (ii) redistributing resources to cope with economic shocks (Gort, 1969; Mitchell and Mulherin, 1996; Maksimovic and Phillips, 2001; Andrade et al., 2001); (iii) reaching new sources of capital (Lang et al., 1989; Holmes and Schmitz, 1995; Maksimovic and Phillips, 2001; Jovanovic and Rousseau, 2002); and iv) taking advantage of mispricing

\footnotetext{
* Corresponding author. Tel.: +90 444 4034; fax: +90 2164745353.

E-mail addresses: nagihancomezdolgan@sehir.edu.tr (N. Çömez-Dolgan), basak@bilkent.edu.tr (B. Tanyeri).
}

in firm shares (Gort, 1969). Moreover, managerial appetite for status (Jensen, 1986), merger related compensation (Hartzell et al., 2004; Grinstein and Hribar, 2004), irrational expectations in the form of hubris in overvaluing targets (Roll 1986), or confirmation bias (Bogan and Just, 2009) may also explain why management may undertake mergers. Cremers et al. (2009), Cornett et al. (2011), and FesciogluUnver and Tanyeri (2013) empirically investigate how a combination of the above factors may motivate mergers.

Operations management literature shows that firms can achieve economies of scale and realize cost savings when they centralize their supply chain decision making. Anecdotal evidence supports this view. According to Bowman (2003), at the time when HP and Compaq merged, the newly merged company was moving products through 109 distribution centers, which was cut in half after the merger. Consequently, within the first nine months of the merger, more than $\$ 1$ billion supply chain related cost savings such as directmaterials procurement, logistics, and factory rationalization were realized. U.S. Department of Justice and Federal Trade Commission (2006) reports the motivation between two consumer product packagers to merge as reducing inventory costs through the consolidation of packaging facilities. Another example is the merger of Kroger Co. and Fred Meyer, Inc. The press release states the firm's "plan to generate [cost] savings through combined procurement of goods and services, reduced corporate overhead, in-market synergies, and consolidation of support services" (Kroger, 1998). Bernile and Bauguess (2010) report 
that 88 percent of publicly released management forecasts on mergers attribute expected cost savings to elimination of duplicate costs of layouts, production capabilities, administration, and R\&D.

According to theoretical studies in operations management, coordinating inventory decisions for different demand sources may decrease inventory costs in two ways. First, merging firms may realize economies of scale by reducing fixed expenses such as transportation and stocking costs. Second, as in the seminal work of Eppen (1979), total safety stock may decrease with inventory pooling, i.e., by keeping joint inventories to satisfy various uncertain demands. Inventory pooling benefits can be obtained by physically combining inventories (Ben-Zvi and Gerchak, 2012; Bouma and Teunter, 2014) as well as, sharing units between separate inventories-defined as inventory sharing (Grahovac and Chakravarty, 2001; Çömez et al., 2012; Satir et al., 2012; Tai and Ching, 2014), coordinating substitutable products' inventory management (Bish and Suwandechochai, 2010; Ye, 2014), delaying the differentiation of the basic product body further down in production, so that a common inventory can be kept for the basic product (Tibben-Lembke et al., 2005; Ngniatedema et al., 2015), or centralizing the inventories of the common components of different end products (Baker et al., 1986; Hillier, 2002).

Factors such as correlation between the demands and the variability in demand may affect the magnitude of benefits from inventory centralization. Gerchak and Mossman (1992) and Corbett and Rajaram (2006) show that as the correlation between the different demand sources decreases, the reduction in inventory costs increases. The results on how demand variation affects inventory efficiencies are mixed. Gerchak and He (2003) and Berman et al. (2011) show conditions under which inventory cost savings may increase or decrease with demand variation. Cai and Du (2009) and Yang and Schrage (2009) provide an extensive review of studies on inventory pooling.

This paper bridges the theoretical work in operations management with the empirical work in corporate finance. We empirically investigate whether merging firms realize benefits associated with centralizing inventory management using firm-level data from 270 same-industry mergers with announcement dates ranging from 1981 to 2009. To test whether merged firms realize any savings associated with inventory efficiencies, we compare the inventory turnover of the combined firm one, two, and three years after the merger is completed to the inventory turnover of the (hypothetically) combined firm one year before the merger is announced. Inventory turnover is defined as the ratio of cost of goods sold to average inventory. We also control for whether the change in inventory turnover is a result of the change in industry inventory performance. For this purpose, we benchmark the change in inventory turnover of the merged firm to the median change in inventory turnover of the industry.

We find no significant increase in inventory turnover of the merged firms with respect to industry median in the full sample. However, this result changes in subsamples split according to demand correlation, which is measured using the correlation in the cost of goods sold of merging firms. We find that in mergers where the demands of the bidder and target firms are negatively correlated, the inventory turnover of the combined firm increases by 12,22 , and 28 percent, respectively, in the one, two, and three years following the merger. There is 1,2 , and 1 percent increase in the median industry turnover of the corresponding mergers, respectively, in the one, two, and three years following the merger. Hence, the change in industry turnover does not explain the improvement in the turnover of the merged firms. Regression analysis confirms that the change in inventory turnover decreases with demand correlation. The results support the theoretical models and indicate that merging firms with negative demand correlation realize inventory efficiencies following mergers. We find no significant effect of demand variation on the change in inventory turnover.
We aim to contribute to the literature by empirically testing theoretical predictions about the inventory pooling benefits and effects of demand variability and correlation on the magnitude of potential benefits in actual mergers and acquisitions context. This study utilizes a novel and large dataset of merging firms. The findings support the predictions of theoretical models and confirm that inventory related synergies arise in mergers where the bidder and target demands are negatively correlated prior to the merger. In line with theoretical predictions, the pre-merger demand correlation is the main driver of merger related inventory synergies. Moreover, this paper sheds additional light on how merging firms realize economies of scale. Results indicate that merged firms realize economies of scale by reducing inventory costs possibly resulting from the coordination of the inventory decisions.

The theoretical work on mergers and empirical work on inventory pooling are scarce in the operations management literature. Gupta and Gerchak (2002) build an analytical model to study the valuation of target firms by considering production characteristics such as capacity and flexibility. Iyer and Jain (2004) use a queueing model to study the expected decrease in inventory costs in a merger of two production-inventory systems. Alptekinoğlu and Tang (2005) derive an analytical model to investigate the cost benefits that are expected to be realized in multi-channel distribution systems, which centralize the ordering and demand allocation decisions. Güneş and Yaman (2010) formulate an integer programming model to solve the matching problem of supply and demand in hospital mergers.

Langabeer (2003), Louis (2004), Davila and Wouters (2007) are empirical studies that investigate the relation between mergers and inventory performance. Langabeer (2003) studies the absolute change in supply chain performance around mergers in chemical and pharmaceutical industries. The author finds that supply chain performance measured as a joint function of inventory turns, finished goods inventory, and operating margin decreases after merger due to adaptation problems. Louis (2004) studies market's efficiency in processing manipulated accounting reports using a sample of merging firms. The author hypothesized inventory turnover to decrease after merger announcements, because expectations of high post-merger demand would drive the bidder to build up inventories before the merger. The author tracked inventory turnover of bidders in the eight quarters around merger announcements but did not employ any statistical tests on the change in inventory turnover. Davila and Wouters (2007) use 18months of firm-level data from a U.S. disk drive manufacturer that has implemented a production postponement strategy. They find that while higher levels of postponement result in higher service levels, inventory turnover does not change.

Our study differs from these three empirical works on mergers and inventory management in two respects. First, we use firmlevel data on 270 merger deals (Davila and Wouters, 2007 focus on one deal) taking place in many industries such as manufacturing, wholesale and retail trade, transportation (Langabeer, 2003, concentrates on deals in pharmaceutical industry). Second, we use both univariate and multivariate statistical analyses to test the hypotheses on inventory turnover, while Louis (2004) relies on summary statistics to describe how inventory turnover evolves around mergers.

The rest of this article is organized as follows. Section 2 develops the hypotheses on inventory efficiencies around mergers relying on theoretical work on inventory centralization. Section 3 describes the hypothesis testing method and the details of the data sample that we utilize. Section 4 discusses the results of the empirical analyses. Finally, Section 5 concludes the paper by summarizing the findings and limitations of the study and providing guidance for follow-up research. 


\section{Hypotheses}

Following a merger where target and bidder firms centralize decision making and start functioning as a single firm, the merged firm may consolidate at least some of its inventory management decisions. Consolidating inventory decisions may affect inventory levels in two ways. First, following the economic order quantity (EOQ) model (Harris, 1913), economies of scale can be achieved in order sizes. Recall that $\sqrt{2 D S / h}$ is the optimal batch size under an EOQ model, where $D$ denotes the demand rate, $S$ is the set-up or order cost, and $h$ is the holding cost per unit, which are assumed to be symmetric for merging firms. Assuming that the merged firm centralizes ordering decisions for two firms that used to make individual ordering decisions for demands $D_{1}$ and $D_{2}$, optimal consolidated batch size cannot be larger than the sum of the individually optimal batch sizes, i.e., $\sqrt{2\left(D_{1}+D_{2}\right) S / h} \leq \sqrt{2 D_{1} S / h}+$ $\sqrt{2 D_{2} S / h}$. As a result, average inventory levels may decrease.

Second, optimal ordering level for consolidated demand can be different from the sum of optimal levels of independently planned inventories due to the change in safety inventory. Eppen (1979) introduced the basic inventory pooling model using newsvendor setting where there is a single season for a single product and orders are prepared at the beginning of the season to satisfy random demands from $N$ different sources. When independently planned, the optimal initial inventory level for a single source $i$ is $F_{i}^{-1}(z)$, where $F_{i}^{-1}($.$) is the inverse distribution function and z$ is the margin contribution of the product. Thus, for $N$ sources, the total unconsolidated initial inventory level is $\sum^{N} F_{i}^{-1}(z)$. On the other hand, when a joint inventory optimization is made, the total optimal order level is $F_{1+2+\cdots+N}^{-1}(z)$. Eppen (1979) proves that when demands are identically normally distributed, the optimal centralized inventory is not greater than the sum of the $N$ inventories optimized separately. Baker et al. (1986) and Stulman (1987) confirm this result with service level constraints. Gerchak and Mossman (1992) and Chen and Lin (1990) show counter results where inventory increases when the ordering decision is centralized using different demand distributions. Yang and Schrage (2009) generalize these results by analytically showing that when demand distributions are right skewed, optimal inventory amount may increase after pooling, defined as inventory anomaly. Using general demand functions, Aydin et al. (2012) show that centralization decreases inventory levels if the marginal contribution parameter is high enough. As many real life distributions are shown to fit to normal distributions, especially when the demand size is large, Hypothesis 1 is defined relying on the results of the theoretical studies that used normal distributions for modeling the demand. In Section 4 , following the discussions of testing of Hypothesis 1, this issue is detailed again.

Hypothesis 1. The post-merger inventory performance of the merged firm improves when compared to the performance of the hypothetically combined pre-merger bidder and target firms.

If centralizing inventory decisions can decrease the stocking amounts, then the next question is what determines the magnitude of this decrease. One parameter that can affect pooling benefits is the correlation between the different demand sources. Gerchak and Mossman (1992) and Gerchak and He (2003) show that as the correlation coefficient between demand sources decreases from 1 to -1 , the pooled demand variability decreases resulting in greater savings in inventory holding costs. Hillier (2000), Benjaafar et al. (2005), Corbett and Rajaram (2006) also conclude that the benefit of pooling increases with the decrease in demand correlation. These theoretical predictions lead to our second hypothesis.

Hypothesis 2. The post-merger inventory performance improvement increases as the pre-merger demand correlation between bidder and target firms decreases.
Variability of the pooled demands may also affect benefits of pooling. For general demand distributions and non-identical demand variabilities, there are mixed results. Concerned about inventory costs, Gerchak and $\mathrm{He}$ (2003) show conditions in which the higher demand variability increases the benefits of pooling, as well as an example where increased variability reduces the benefits of risk pooling. Using a model in which supply lead times are endogenous, Benjaafar et al. (2005) show that increasing demand variability decreases the benefit of pooling, which diminishes at very high variability. Berman et al. (2011) analyze inventory pooling with a distribution-free approach for multiple identical and independent demand sources. They conclude that when the variation is below a threshold level, while the absolute cost savings (difference in costs) is increasing in variability, the relative savings (ratio of costs) is constant. Beyond this threshold, both the absolute and relative savings decrease in variation and become zero as variation increases further. Hypothesis 3 tests the predictions of these theoretical models.

Hypothesis 3. The post-merger inventory performance improves with the pre-merger demand variability of bidder and target firms.

\section{Sampling frame}

We compile the sample of merger deals using Security Database Corporation's (SDC) U.S. Mergers and Acquisition database. Our aim is to investigate whether merging firms improve their inventory performance and the effects of demand characteristics on potential changes. We expect inventory economies to arise in deals where the operations of bidder and target are centralized after the merger and the bidder and target carry similar types of inventories. We impose the following filters to identify a sample of deals where inventory pooling strategy would be most likely enacted. First, to centralize operations, deals should be completed and bidders should purchase control rights in the targets. Second, bidders and targets should operate in the same industry. For this purpose, mergers are restricted to the ones where bidder and target share the same 2-digit Standard Industrial Classification (SIC) code. Although, restricting the merging firms to the same 3 or 4-digit SIC code would identify mergers taking place in more similar industries, it significantly reduces the available dataset for statistical analysis. Third, bidder and target should be non-financial firms since financial firms carry no significant amount of inventory. Fourth, we drop all merger deals by the same target or bidder (except for the first one) in order to attribute the change in inventory performance to the specific merger. These filters produce 7,598 deals with announcement dates ranging from January 1981 to November 2009.

We compile financial statement data on merging firms using COMPUSTAT quarterly database. We collect data on cost of goods sold, inventory, and total assets (COMPUSTAT data items are "cogsq", "inventory turnoverq", and "atq", respectively). Rumyantsev and Netessine (2007) show that inventory fluctuates in time with demand and production seasonality. This is why we use the most frequent data available which is quarterly. Fig. 1 shows the merger timeline. Announcement date is the day on which bidder and target announce their intention to merge and negotiations begin. Effective date is the date on which negotiations are successfully concluded and bidder and target firms legally merge. The time between announcement and effective dates marks a period of negotiation and transition. As a result, the inventory policies within this period may be unusual due to the transition in operations (Louis, 2004). This is why we restrict premerger analysis to one year before the announcement and the postmerger analysis to one to three years after the effective date.

We require bidder and target to have data on sales, cost of goods sold, and inventory in at least one quarter prior to announcement date and in at least one quarter of each of the three years following the effective date. If a merging firm has less than four quarters of financial 


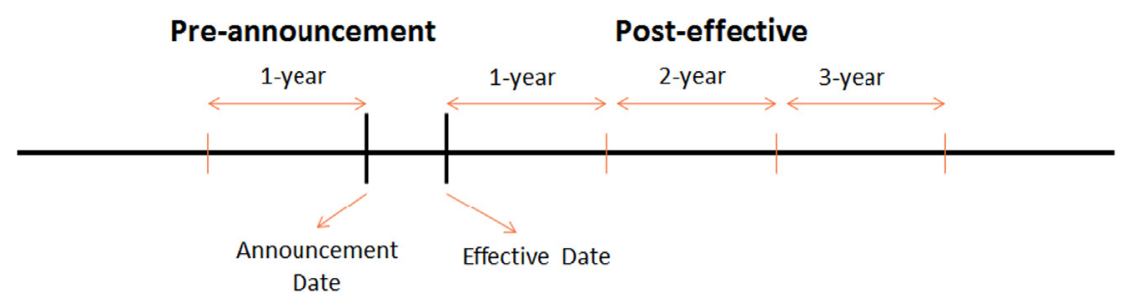

Fig. 1. Merger timeline.

data in any year, we extrapolate the missing data by taking the average of the available data in that year. The availability of financial statement data on bidder and target firms prior to the merger and on the merged firm after the merger reduces the sample to 270 deals. Table 1 tabulates the distribution of the deals according to industry. 64 percent of deals take place in the manufacturing industry, 12 percent in transportation and 11 percent in retail trade industries.

Inventory pooling theory measures inventory in units. However, data on inventory is available in dollars. Theory also assumes that demand is stationary in time. In practice, demands of merging firms need not be stationary in time due to seasonality, macro-economic factors, competition, and changing customer preferences (Rumyantsev and Netessine, 2007). Moreover, one of the reasons for undertaking mergers is to increase the market share and demand of merging firms (Gugler et al., 2003). As a result, change in inventory may arise due to the change in demand and not the effect of inventory pooling. Our data shows that in the four-year window around the merger, cost of goods sold (a measure of dollar demand) increases by 6 percent annually on average. To isolate the effect of inventory pooling from the change in demand, we use inventory turnover as the measure of inventory performance. Inventory turnover normalizes inventory by cost of goods sold and accounts for the effect of the change in demand. When using inventory turnover, there is no need to deflate cost of goods sold and inventory. Both the numerator and denominator in inventory turnover are in dollars and affected by inflation (see also Rajagopalan and Malhotra, 2001; Chen et al., 2005; Rumyantsev and Netessine, 2007).

We calculate annual inventory turnover by dividing the aggregated quarterly cost of goods sold by average quarterly inventory. We drop observations with inventory turnover less than 1 or greater than 100 to eliminate outliers (Chen et al., 2005). Let $\operatorname{Cogs}_{t q}^{i}$ denote the cost of goods sold by firm $i$ in quarter $q$ of year $t$ and $\operatorname{Inv}_{t q}^{i}$ the inventory level at the end of quarter $q$ of year $t$. Then, the inventory turnover of firm $i$ in year $t$ denoted by $\operatorname{Inv} T_{t}^{i}$ is:

$\operatorname{Inv} T_{t}^{i}=\frac{\sum_{q=1}^{4} \operatorname{Cog}_{t q}^{i}}{\left(\sum_{q=1}^{4} \operatorname{In} v_{t q}^{i}\right) / 4}$

In the same spirit as Harris et al. (2000), we compute premerger combined inventory turnover by summing the annual cost of goods sold for the bidder and target and dividing it by their average combined inventories in the year before the announcement. For this purpose, $\operatorname{Cog} s_{t}^{i}=\sum_{q=1}^{4} \operatorname{Cog} s_{t q}^{i}$ denotes the annual cost of goods of firm $i$ in year $t$ and $\operatorname{In} v_{t}^{i}=\left(\sum_{q=1}^{4} \operatorname{In} v_{t q}^{i}\right) / 4$ denotes the average inventory of the firm in year $t$. Pre-merger inventory turnover of the hypothetically merged firm is denoted by $I n v T_{t-1}$. Post-merger inventory turnover of the merged firm is calculated in each of the three years following effective date and denoted by $I n v T_{t+j}$, for $j \in\{1,2,3\}$. Below, superscript $b$ denotes the bidder and
Table 1

Industry distribution of sample deals.

\begin{tabular}{|c|c|c|}
\hline 2-Digit SIC code & Industry definition & $\begin{array}{l}\text { Sample total } \\
(\%)\end{array}$ \\
\hline $10,12,13,15$ & Mining & 5 \\
\hline $\begin{array}{l}20,22-23,25-30,32- \\
\quad 39\end{array}$ & Manufacturing & 64 \\
\hline $40,45,48-49$ & $\begin{array}{l}\text { Transportation and communication } \\
\text { services }\end{array}$ & 12 \\
\hline $50-51$ & Wholesale trade & 2 \\
\hline $52-59$ & Retail trade & 11 \\
\hline $72,73,75,79,80,87$ & Services & 5.6 \\
\hline 99 & Other & 0.7 \\
\hline \multicolumn{3}{|c|}{ Sample size $(N): 270$} \\
\hline
\end{tabular}

$g$ denotes the target firm.

$\operatorname{Inv} T_{t-1}=\frac{\operatorname{Cog} s_{t-1}^{b}+\operatorname{Cog} s_{t-1}^{g}}{\operatorname{In} v_{t-1}^{b}+\operatorname{In} v_{t-1}^{g}}$

$\operatorname{Inv} T_{t+j}=\frac{\operatorname{Cog} s_{t+j}^{b}}{\operatorname{In} v_{t+j}^{b}}$

We estimate demand variation of bidder and target firms and the demand correlation between the bidder and target by using cost of goods sold as a proxy for demand. Sales can also proxy for demand (Cachon et al., 2007). We estimate the demand correlation using the correlation between the cost of goods sold for the bidder and target firms before the effective date. In the spirit of Randall et al. (2006), we compute the coefficient of variation to measure demand variability. We require bidder and target to have at least three quarters of data before the merger announcement to estimate demand correlation and variation. The number of quarters used to estimate correlation and coefficient of variation ranges from 3 to 125 quarters with a mean of 35 quarters. The deals with early announcement dates have less number of quarters prior to the announcement to estimate correlation and coefficient of variation.

Table 2 shows descriptive statistics for the bidders, targets, and hypothetically merged firms in the one year before the announcement and on the merged firm in the three years following the effective date. There are 270 deals in the sample. However, we could not find data on cost of goods sold and inventory in the three years following the merger for all deals. We can calculate inventory turnover in the one year following effective date for all merged firms, in the two years for 248 firms, and in the three years following for 230 firms. To track firms through time, we required that merged firms have data on all years following the merger. When we relax the requirement, the results remain qualitatively the same. Both inventory and cost of goods sold of the merged firm increase following the effective date relative to the inventory and cost of goods sold of the hypothetically merged firm prior to announcement. Table 2 also shows that the size (measured as the book value of assets) of the merged firm increases relative to that of the hypothetically combined firm prior to the announcement date. 
Table 2

Descriptive statistics for bidders, targets, and merged firms (in million \$).

\begin{tabular}{|c|c|c|c|c|c|c|}
\hline & \multicolumn{3}{|c|}{$\begin{array}{l}\text { The year prior to merger } \\
\text { announcement }\end{array}$} & \multicolumn{3}{|c|}{$\begin{array}{l}\text { Years following } \\
\text { the merger } \\
\text { effective date }\end{array}$} \\
\hline & \multirow[b]{2}{*}{ Bidder } & \multirow[b]{2}{*}{ Target } & \multirow[b]{2}{*}{ Combined } & & & 3 \\
\hline & & & & \multicolumn{3}{|c|}{ Merged Firm } \\
\hline COGS & 1864 & 494 & 2358 & 2605 & 2768 & 2815 \\
\hline Inventory & 294 & 76 & 370 & 412 & 425 & 427 \\
\hline Size (total assets) & 2499 & 616 & 3115 & 3792 & 4083 & 4345 \\
\hline COGS (industry median) & \multicolumn{3}{|c|}{212} & 218 & 252 & 271 \\
\hline Inventory (industry median) & \multicolumn{3}{|c|}{30} & 32 & 37 & 43 \\
\hline
\end{tabular}

Table 2 shows that inventory and cost of goods sold for the median firm in the industry of merging firms is increasing. We use the median firm and not the mean firm since the mean may be affected by extreme values (Chen et al., 2005). Hence, the increase in cost of goods sold and inventory of merged firms may be an industry-wide effect. Rajagopalan and Malhotra (2001), Chen et al. (2005), Gaur et al. (2005) state that due to production planning practices such as just-in-time and use of computerized stock planning systems, inventories tend to decrease. On the other hand, economic fluctuations, changes in end customer demand patterns, oil prices, as well as competition may lead to an overall inventory pile up in an industry. Because of industry-wide trends, the inventory performance of a merger should not be evaluated in isolation from its industry. Hence we benchmark the change in inventory and cost of goods sold of a merging firm against the change in the median firm in its industry.

\section{Results}

The first hypothesis investigates whether the inventory performance of the merged firm improves relative to the pre-merger performance of bidder and target firms. If the hypothesis holds, inventory turnover of the combined firm following the merger should prove higher than the inventory turnover of the hypothetically combined firm prior to the merger. Industry-wide trends can affect the inventory policy of individual firms. As a result, we benchmark the change in inventory turnover of the merged firm to that of the median firm in its industry. We measure the change in inventory turnover in two ways. First, we take the ratio of inventory turnover in the three years following effective date to inventory turnover in the one year before the announcement. Second, we take the difference of inventory turnover in the three years following effective date and inventory turnover in the one year before the announcement. Benjaafar et al. (2005) and Berman et al. (2011) utilize a similar dual comparison method in their analytical studies.

Panel A of Table 3 compares the change in inventory turnover of the merging firms to the change in inventory turnover of the median firm in the industry, which is denoted by superscript $m$ for each of the three years following the merger, i.e., $j=1,2,3$, in terms of both ratio and difference change in inventory turnover. The inventory turnover of the merged firm increases by: 2 percent in the one year, 4 percent in the two years, and 6 percent in the three years following the effective date. In the three years following the effective date, industry turnover increases by at most 2 percent. Testing for whether the improvement in inventory turnover of the merged firm is different than the change in turnover for the median firm in the industry, we find the difference to be significant in the third year following the merger. Table 3, like Table 2, requires that merged firms have data on all years following the merger. When we relax the requirement, the results remain qualitatively the same and are statistically more significant.

We also evaluate the change in inventory turnover around the merger by taking the absolute difference between the postinventory turnover of merged firm and the pre-inventory turnover of the hypothetically combined firm $\left(\operatorname{Inv} T_{t+j}-\operatorname{Inv} T_{t-1}\right)$ for $j=1,2$, 3. The difference in inventory turnover of the merged firms relative to the change in the inventory turnover of median industry firm proves negative and insignificant in the three years following the effective date as reported in Panel A of Table 3. The evidence from the ratio test and the difference test is contradictory. The ratio test indicates that turnover relative to industry increases (albeit at no statistical significance for the first two years) whereas the difference test indicates that turnover decreases (again at no statistical significance in all three years).

The difference in tests is due to size of inventory turnover. The ratio test looks at the relative change in performance and gives equal weight to all merging firms in the sample. The difference test looks at the absolute change in performance and gives higher weight to merging firms, which had larger inventory turnovers to begin with. This indicates that merging firms who had large inventory turnovers prior to the merger announcement improved their inventory turnover ratios less after the effective date when compared to firms who had small inventory turnover ratios to begin with.

Full sample results in Panel A do not fully support the hypothesis that inventory efficiencies improve after the merger. The second hypothesis calibrates the first hypothesis and states that merging firms with low demand correlation should benefit most from the merger in terms of inventory economies. As such, we construct two subsamples, one that contains deals with negative demand correlation (Panel B) and one that contains deals with positive demand correlation (Panel C) before the merger.

In deals with negative demand correlation, inventory turnover of the merged firm increases by 12,22 , and 28 percent in the 1,2 , and 3 years following the effective date, respectively. This increase when benchmarked against the change in the median industry firm proves significant at less than five percent. The results of inventory turnover difference tests are qualitatively similar. The difference in inventory turnover proves positive and when benchmarked against the median industry firm, it is marginally significant in the one and two years following the merger and significant in the three years following the merger. We fail to find any significant change in inventory turnover for merging firms with positive demand correlation.

The results indicate that in an average merger, inventory performance does not increase significantly (evidenced in Panel A). It is in deals of merging firms with negative demand correlations that inventory performance increases (evidenced in Panel B). We attribute the increases in inventory turnover to the possible centralization of inventory management following mergers. As we do not have information on the individual policy changes that are enacted following a merger, we cannot forcefully say the results are due to a strategic change to pool inventories. However, in the spirit of Occam's razor, the simplest explanation that is provided by inventory pooling theory would explain our results.

Hypothesis 1 is based on the stream of theoretical studies that model normal demand distributions such as the earliest work of Eppen (1979). Based on the skewness coefficients for cost of goods sold, which is our proxy for demand, we tested and rejected the null hypothesis for a normally distributed demand for both the target and bidder prior to the merger in 66 out of the 230 deals. We conducted unreported (available upon request from authors) robustness tests using the sample of 66 normal distribution rejects and the 164 non-rejects. Our results regarding the inventory turnover following a merger remain qualitatively the same (and 
Table 3

Change in inventory turnover of merged firms relative to the change in inventory turnover of the industry median.

\begin{tabular}{|c|c|c|c|c|c|c|}
\hline & \multicolumn{3}{|c|}{ Inventory turnover ratio test } & \multicolumn{3}{|c|}{ Inventory turnover difference test } \\
\hline & $\frac{\operatorname{Inv} T_{t+j}}{\operatorname{Inv} T_{t-1}}$ & $\frac{\operatorname{Inv} T_{t+j}^{m}}{\operatorname{Inv} T_{t-1}^{m}}$ & $p$-Value of $t$-tests & $\operatorname{Inv} T_{t+j}-\operatorname{Inv} T_{t-1}$ & $\operatorname{Inv} T_{t+j}^{m}-I n v T_{t-1}^{m}$ & $p$-Value of $t$-tests \\
\hline Panel A: full sample & $N=230$ & & & & & \\
\hline$j=1$ & 1.02 & 1.01 & 0.33 & -0.43 & 0.13 & 0.93 \\
\hline$j=2$ & 1.04 & 1.01 & 0.20 & -0.25 & 0.08 & 0.75 \\
\hline$j=3$ & 1.06 & 1.01 & 0.06 & -0.06 & 0.07 & 0.61 \\
\hline Panel B: Firms with $(-)$ correlation & $N=58$ & & & & & \\
\hline$j=1$ & 1.12 & 1.01 & 0.04 & 0.88 & 0.07 & 0.10 \\
\hline$j=2$ & 1.22 & 1.02 & 0.03 & 1.51 & 0.13 & 0.09 \\
\hline$j=3$ & 1.28 & 1.01 & 0.01 & 2.18 & 0.01 & 0.02 \\
\hline Panel C: Firms with $(+)$ correlation & $N=172$ & & & & & \\
\hline$j=1$ & 0.99 & 1.01 & 0.82 & -0.87 & 0.16 & 0.99 \\
\hline$j=2$ & 0.98 & 1.00 & 0.81 & -0.84 & 0.07 & 0.95 \\
\hline$j=3$ & 0.99 & 1.00 & 0.70 & -0.81 & 0.09 & 0.98 \\
\hline
\end{tabular}

indeed are more pronounced) in the subsample covering deals where the normality assumption is not rejected.

Tables 4 and 5 investigate the factors that affect the change in inventory turnover of merging firms using regression analysis. In all regression specifications, the dependent variable is the ratio of postinventory turnover (one year after the effective date in Panel A, two years in Panel B, and three years in Panel C) to pre-inventory turnover (one year before announcement date) in Table 4 and the difference of post-inventory turnover from pre-inventory turnover in Table 5. The first column in both tables shows the mean (in the first row) and the standard deviation (in the second row) of the independent variables. Industry inventory turnover has three entries denoting the post 1,2 , and 3 years' performances, respectively. The mean and standard deviation of the dependent variables are shown in the first rows of the tables. In the first regression specification, we only include the variable of interest, the demand correlation between bidder and target prior to the effective date. In the second through fourth specifications, we introduce the variables that proxy for factors that may affect the change in inventory turnover one by one. Namely, we introduce controls for: the industry, bidder and target coefficient of variation, pre-merger inventory turnover, and firm size. In the second specification, the independent variables are demand correlation and the change in inventory turnover of the median industry firm. In the third specification, we introduce bidder and target coefficient of variation $(c v)$. In the fourth specification, we add the following control variables: the ratio of pre-merger inventory turnover of the bidder to the target and bidder and target sizes.

In all regression specifications in Tables 4 and 5 , the change in inventory turnover of merging firms is inversely related to the demand correlation between bidder and target. The negative relation between change in inventory turnover and correlation proves significant in the two-year window and marginally significant in the three-year window in the inventory turnover ratio regressions. The negative relation also proves marginally significant in the two- and three-year windows in the inventory turnover difference regressions. The results support the second hypothesis, which states that centralizing the inventory decision for demand sources with negative correlation will prove most beneficial.

In all regression specifications in Tables 4 and 5 , the bidder coefficient of variation is negative. The negative bidder coefficient of variation proves significant in the one-year window in inventory turnover ratio and difference regressions. The target coefficient of variation proves positive in all but two ratio regressions, and it is significant in the threeyear window of the ratio regression. Results show that demand variations at bidder and target firms tend to affect the inventory benefits in opposite directions. Therefore, our results partially support the third hypothesis; while the demand variation of the bidder decreases, the demand variation at the target increases the inventory pooling benefits.
The results indicate that industry-wide trends in inventory do affect individual firm inventory turnover. The change in the inventory turnover of the median industry firm proves positive and significant in all specifications in Tables 4 and 5. The control variables, relative pre-inventory efficiency of bidder, bidder and target size, all prove insignificant.

The adjusted $R^{2}$ in Tables 4 and 5 ranges upto 11 percent. Chen et al. $(2005,2007)$ attain higher $R^{2}$ in their models of inventory turnover. The higher explanatory power of these models may be attributed to their use of a greater number of independent variables and their use of the time trend. In this study, we focus on the change rather than the level of inventory turnover. Furthermore, we report adjusted $R^{2}$. Rumyantsev and Netessine (2007) investigate days in inventory and similar to our models' explanatory power their adjusted $R^{2}$ ranges from 4 to 29 percent. Finally, we only try to proxy for factors that may affect the change in inventory turnover as suggested by inventory pooling theory. These three factors may explain why the adjusted $R^{2}$ in our regressions prove lower.

To summarize, we find that the inventory turnovers of bidder and target firms improve (relative to firms in their industry) following the successful completion of mergers. We also find that the improvement in inventory turnover is inversely related with the demand correlation between bidder and target firms. Our results provide empirical support for the predictions of theoretical models on inventory pooling.

\section{Summary of findings and directions for further research}

In this study, we aim to contribute to empirical research in operations management and corporate finance by testing the theory on centralizing inventory decisions using a sample of merging firms. On the one hand, theoretical models in operations management show that coordinating the inventory decisions for demands from different sources may decrease the optimal amount of inventory needed through both deterministic and statistical economies of scale. On the other hand, research in corporate finance states economies of scale and scope as an important merger motive, but does not focus on inventory efficiencies explicitly. So, the question of whether and how economies of scale are actually achieved in mergers remained unanswered. This study aims to answer this question by empirically testing the hypotheses of theoretical models in mergers and acquisitions context.

After restricting the merger deals to those: completed in similar industries, that have financial data four years around the merger activity, and that operate in non-financial services, we end up with 270 deals. We measure inventory performance using inventory turnover. Previous studies show that inventory turnover is not constant in 
Table 4

Regression analysis of (ratio) change in inventory turnover of merged firms.

\begin{tabular}{|c|c|c|c|c|c|c|c|c|c|c|c|c|c|}
\hline \multirow[t]{2}{*}{ Model } & \multirow[t]{2}{*}{ Descriptive statistics } & \multicolumn{4}{|c|}{$\begin{array}{l}\operatorname{Inv} T_{t+1} / \operatorname{InvT_{t-1}}(j=1) \\
1.00,[0.39]\end{array}$} & \multicolumn{4}{|c|}{$\begin{array}{l}\operatorname{Inv} T_{t+2} / \operatorname{Inv} T_{t-1}(j=2) \\
1.03,[0.56]\end{array}$} & \multicolumn{4}{|c|}{ 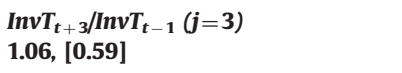 } \\
\hline & & (1) & (2) & (3) & (4) & (1) & (2) & (3) & (4) & (1) & (2) & (3) & (4) \\
\hline Correlation coefficient & $\begin{array}{l}0.39 \\
{[0.45]}\end{array}$ & $\begin{array}{l}-6.69 \\
{[1.28]}\end{array}$ & $\begin{array}{l}-6.13 \\
{[1.19]}\end{array}$ & $\begin{array}{l}-4.33 \\
{[0.84]}\end{array}$ & $\begin{array}{c}-4.73 \\
{[0.90]}\end{array}$ & $\begin{array}{l}-18.17^{\text {*** }} \\
{[2.32]}\end{array}$ & $\begin{array}{l}-15.50^{* *} \\
{[2.00]}\end{array}$ & $\begin{array}{l}-14.69 * \\
{[1.88]}\end{array}$ & $\begin{array}{l}-15.19 * \\
{[1.90]}\end{array}$ & $\begin{array}{l}-15.39 * \\
{[1.82]}\end{array}$ & $\begin{array}{l}-12.52 \\
{[1.52]}\end{array}$ & $\begin{array}{l}-9.67 \\
{[1.19]}\end{array}$ & $\begin{array}{l}-10.68 \\
{[1.29]}\end{array}$ \\
\hline $\operatorname{Inv} T_{t+\mathrm{j}}^{m} / \operatorname{Inv} T_{t-1}^{m}$ & $\begin{array}{l}1.01,1.01,1.00 \\
{[0.09,0.10,0.09]}\end{array}$ & & $\begin{array}{l}73 * * * * \\
{[2.96]}\end{array}$ & $\begin{array}{l}70^{* * * \cdots *} \\
{[2.86]}\end{array}$ & $\begin{array}{l}70^{* * * * *} \\
{[2.79]}\end{array}$ & & 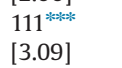 & $\begin{array}{l}108^{* * * * *} \\
{[2.99]}\end{array}$ & $\begin{array}{l}107^{* * * * *} \\
{[2.91]}\end{array}$ & & $\begin{array}{l}152^{* * * * * *} \\
{[3.95]}\end{array}$ & $\begin{array}{l}140^{* * * * *} \\
{[3.73]}\end{array}$ & $\begin{array}{l}144^{* * * * *} \\
{[3.79]}\end{array}$ \\
\hline Bidder $c v$ & $\begin{array}{l}0.61 \\
{[0.31]}\end{array}$ & & & 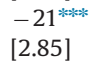 & $\begin{array}{l}-20^{\text {*****k }} \\
{[2.63]}\end{array}$ & & & $\begin{array}{c}-9.03 \\
{[0.79]}\end{array}$ & $\begin{array}{l}-11.18 \\
{[0.96]}\end{array}$ & & & $\begin{array}{l}-14.99 \\
{[1.28]}\end{array}$ & $\begin{array}{l}-12.36 \\
{[1.03]}\end{array}$ \\
\hline Target $c v$ & $\begin{array}{l}0.52 \\
{[0.32]}\end{array}$ & & & $\begin{array}{l}6.37 \\
{[0.89]}\end{array}$ & $\begin{array}{l}6.66 \\
{[0.92]}\end{array}$ & & & $\begin{array}{l}2.78 \\
{[0.24]}\end{array}$ & $\begin{array}{l}2.61 \\
{[0.23]}\end{array}$ & & & $\begin{array}{l}44^{* * * *} \\
{[3.52]}\end{array}$ & $\begin{array}{l}45^{* * * * *} \\
{[3.57]}\end{array}$ \\
\hline $\operatorname{Inv} T_{t-1}^{\mathrm{b}} / \operatorname{Inv} T_{t-1}^{\mathrm{g}}$ & $\begin{array}{l}1.52 \\
{[1.58]}\end{array}$ & & & & $\begin{array}{l}{[.32]} \\
-1.32 \\
{[0.88]}\end{array}$ & & & & $\begin{array}{l}2.15 \\
{[0.94]}\end{array}$ & & & & $\begin{array}{l}-2.78 \\
{[1.08]}\end{array}$ \\
\hline Bidder size & $\begin{array}{l}\$ 2,308 \\
{[\$ 4,518]}\end{array}$ & & & & $\begin{array}{l}0 \\
{[0.07]}\end{array}$ & & & & $\begin{array}{l}0 \\
{[0.57]}\end{array}$ & & & & $\begin{array}{l}0 \\
{[0.22]}\end{array}$ \\
\hline Target size & $\begin{array}{l}\$ 578 \\
{[\$ 1,731]}\end{array}$ & & & & $\begin{array}{l}0 \\
{[0.17]}\end{array}$ & & & & $\begin{array}{l}0 \\
{[0.10]}\end{array}$ & & & & $\begin{array}{l}0 \\
{[0.66]}\end{array}$ \\
\hline Intercept & & $\begin{array}{l}103^{\text {***** }} \\
{[33.11]}\end{array}$ & $\begin{array}{l}29 \\
{[1.15]}\end{array}$ & $\begin{array}{l}41 \\
{[1.58]}\end{array}$ & $\begin{array}{l}42 \\
{[1.57]}\end{array}$ & $\begin{array}{l}110^{* * * * * *} \\
{[23.49]}\end{array}$ & $\begin{array}{c}-2.71 \\
{[0.07]}\end{array}$ & $\begin{array}{l}3.74 \\
{[0.10]}\end{array}$ & $\begin{array}{l}2.53 \\
{[0.06]}\end{array}$ & $\begin{array}{l}112^{\text {****** }} \\
{[22.24]}\end{array}$ & $\begin{array}{l}-41 \\
{[1.05]}\end{array}$ & $\begin{array}{l}-44 \\
{[1.13]}\end{array}$ & $\begin{array}{l}-46 \\
{[1.16]}\end{array}$ \\
\hline$N$ & & 270 & 270 & 270 & 270 & 248 & 248 & 248 & 248 & 230 & 230 & 230 & 230 \\
\hline Adj. $R^{2}(\%)$ & & 0.24 & 3.04 & 5.28 & 4.49 & 1.75 & 5.06 & 4.53 & 3.84 & 1 & 6.95 & 11.26 & 10.73 \\
\hline$F$-test & & 1.64 & 5.21 & 4.75 & 2.81 & 5.39 & 7.58 & 3.93 & 2.41 & 3.31 & 9.55 & 8.26 & 4.93 \\
\hline
\end{tabular}

Notes: Regression coefficients are reported in percent. $t$-Statistics are shown in square brackets.

* Denotes statistical significance at $10 \%$ levels.

** Denotes statistical significance at 5\% levels.

*** Denotes statistical significance at $1 \%$ levels.

Table 5

Regression analysis of the (difference) change in inventory turnover of merged firms.

\begin{tabular}{|c|c|c|c|c|c|c|c|c|c|c|c|c|c|}
\hline \multirow[t]{2}{*}{ Model } & \multirow[t]{2}{*}{ Descriptive statistics } & \multicolumn{4}{|c|}{$\begin{array}{l}I n v T_{t+1}-\operatorname{Inv} T_{t-1}(j=1) \\
-0.59,[6.11]\end{array}$} & \multicolumn{4}{|c|}{$\begin{array}{l}\operatorname{Inv} T_{t+2}-\operatorname{Inv} T_{t-1}(j=2) \\
-0.46,[7.50]\end{array}$} & \multicolumn{4}{|c|}{ 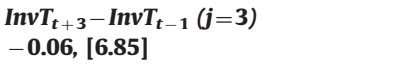 } \\
\hline & & (1) & $(2)$ & (3) & (4) & (1) & (2) & (3) & (4) & (1) & (2) & (3) & (4) \\
\hline Correlation coefficient & $\begin{array}{l}0.39 \\
{[0.45]}\end{array}$ & $\begin{array}{r}-1.18 \\
{[1.43]}\end{array}$ & $\begin{array}{l}-1.23 \\
{[1.53]}\end{array}$ & $\begin{array}{l}-0.96 \\
{[1.19]}\end{array}$ & $\begin{array}{l}-1.13 \\
{[1.37]}\end{array}$ & $\begin{array}{l}-2.30^{* * *} \\
{[2.21]}\end{array}$ & $\begin{array}{l}-2.04^{* * *} \\
{[2.01]}\end{array}$ & $\begin{array}{l}-2.00^{*} \\
{[1.94]}\end{array}$ & $\begin{array}{l}-2.05^{*} \\
{[1.95]}\end{array}$ & $\begin{array}{l}-1.97^{* *} \\
{[2.00]}\end{array}$ & $\begin{array}{l}-1.95^{* *} \\
{[2.04]}\end{array}$ & $\begin{array}{l}-1.70^{*} \\
{[1.77]}\end{array}$ & $\begin{array}{l}-1.81^{*} \\
{[1.83]}\end{array}$ \\
\hline$I n v T_{t+j}^{m}-I n v T_{t-1}^{m}$ & $\begin{array}{l}0.10,0.07,0.07 \\
{[1.32,1.40,1.46]}\end{array}$ & & $\begin{array}{l}1.01^{\text {*k*k }} \\
{[3.67]}\end{array}$ & $\begin{array}{l}0.99 * * * * \\
{[3.64]}\end{array}$ & $\begin{array}{l}0.94^{* * k * k} \\
{[3.25]}\end{array}$ & & $\begin{array}{l}1.26^{* k \cdots * k} \\
{[3.91]}\end{array}$ & $\begin{array}{l}1.25^{* * * * *} \\
{[3.87]}\end{array}$ & $\begin{array}{l}1.20^{* * * * *} \\
{[3.66]}\end{array}$ & & $\begin{array}{l}1.11^{* * * *} \\
{[3.93]}\end{array}$ & $\begin{array}{l}1.09^{* * * * \cdots} \\
{[3.87]}\end{array}$ & $\begin{array}{l}1.08^{* * * * *} \\
{[3.75]}\end{array}$ \\
\hline Bidder $c v$ & $\begin{array}{l}0.61 \\
{[0.31]}\end{array}$ & & & $\begin{array}{l}-3.07^{* * * *} \\
{[2.64]}\end{array}$ & $\begin{array}{l}-3.02^{* * * *} \\
{[2.60]}\end{array}$ & & & $\begin{array}{l}-0.76 \\
{[0.51]}\end{array}$ & $\begin{array}{l}-0.85 \\
{[0.57]}\end{array}$ & & & $\begin{array}{l}-2.02 \\
{[1.45]}\end{array}$ & $\begin{array}{l}-2.06 \\
{[1.47]}\end{array}$ \\
\hline Target $c v$ & $\begin{array}{l}0.52 \\
{[0.32]}\end{array}$ & & & $\begin{array}{l}1.2 \\
{[1.07]}\end{array}$ & $\begin{array}{l}0.97 \\
{[0.85]}\end{array}$ & & & $\begin{array}{l}-0.7 \\
{[0.46]}\end{array}$ & $\begin{array}{c}-0.63 \\
{[0.42]}\end{array}$ & & & $\begin{array}{l}2.31 \\
{[1.55]}\end{array}$ & $\begin{array}{l}2.35 \\
{[1.57]}\end{array}$ \\
\hline$I n v T_{t-1}^{b}-I n v T_{t-1}^{g}$ & $\begin{array}{c}-8.33 \\
{[81.97]}\end{array}$ & & & & $\begin{array}{c}-0.01 \\
{[1.62]}\end{array}$ & & & & $\begin{array}{l}0.01 \\
{[1.54]}\end{array}$ & & & & $\begin{array}{l}0 \\
{[0.19]}\end{array}$ \\
\hline Bidder size & $\begin{array}{l}\$ 2,308 \\
{[\$ 4,518]}\end{array}$ & & & & $\begin{array}{l}0 \\
{[0.71]}\end{array}$ & & & & $\begin{array}{l}0 \\
{[0.99]}\end{array}$ & & & & $\begin{array}{l}0 \\
{[0.64]}\end{array}$ \\
\hline Target size & $\begin{array}{l}\$ 578 \\
{[\$ 1,731]}\end{array}$ & & & & $\begin{array}{l}0 \\
{[0.18]}\end{array}$ & & & & $\begin{array}{l}0 \\
{[0.19]}\end{array}$ & & & & $\begin{array}{l}0 \\
{[0.04]}\end{array}$ \\
\hline Intercept & & $\begin{array}{l}-0.13 \\
{[0.27]}\end{array}$ & $\begin{array}{c}-0.21 \\
{[0.45]}\end{array}$ & $\begin{array}{l}0.94 \\
{[0.97]}\end{array}$ & $\begin{array}{l}0.85 \\
{[0.88]}\end{array}$ & $\begin{array}{l}0.44 \\
{[0.71]}\end{array}$ & $\begin{array}{l}0.28 \\
{[0.45]}\end{array}$ & $\begin{array}{l}1.09 \\
{[0.87]}\end{array}$ & $\begin{array}{l}0.97 \\
{[0.77]}\end{array}$ & $\begin{array}{l}0.71 \\
{[1.20]}\end{array}$ & $\begin{array}{l}0.63 \\
{[1.10]}\end{array}$ & $\begin{array}{l}0.58 \\
{[0.49]}\end{array}$ & $\begin{array}{l}0.46 \\
{[0.38]}\end{array}$ \\
\hline$N$ & & 270 & 270 & 270 & 270 & 248 & 248 & 248 & 248 & 230 & 230 & 230 & 230 \\
\hline Adj. $R^{2}(\%)$ & & 0.38 & 4.81 & 6.7 & 6.89 & 1.54 & 6.94 & 6.39 & 6.57 & 1.29 & 7.18 & 7.98 & 6.97 \\
\hline F-test & & 2.04 & 7.79 & 5.83 & 3.85 & 4.87 & 10.21 & 5.21 & 3.48 & 3.99 & 9.85 & 5.96 & 3.45 \\
\hline
\end{tabular}

Notes: $t$-Statistics are shown in square brackets.

* Denotes statistical significance at $10 \%$ levels.

*** Denotes statistical significance at $5 \%$ levels.

**** Denotes statistical significance at $1 \%$ levels.

time and there are industry-wide trends. So, we tested whether merged firms improved their inventory turnover relative to the median firm in their industry.

While the results do not indicate significant inventory performance improvements for the average merger, we find significant improvement in inventory performance for bidder and target firms with negative demand correlation. Theory predicts that the benefits from inventory pooling increases as the correlation between the pooled demand sources decreases. Our results support the predictions of theoretical work and show that in mergers where the bidder and target firms have negative demand correlation before the merger, the improvement in inventory performance is significantly higher than the improvement in their industries.

We find no significant effects of demand variation on pooling benefits. Actually, the results are consistent with theoretical findings. First, theoretical studies deal with either symmetric systems or consider the demand variability increase in only one of the demand sources, and find contradictory effects of variability on pooling benefits. In a real merger, the symmetry of firms in terms of demand variation cannot be guaranteed and we need to consider the individual variations of each 
firm. Second, Berman et al. (2011) show non-monotonic effects of variability. When the variation is below a threshold level, the absolute cost savings is increasing in variability, but beyond this threshold, the savings decreases. Thus, we believe that the effect of demand variability requires a more detailed analysis including data splitting according to the size of demand variability consistent with the theoretical findings. Moreover, while we use the coefficient of variation to measure demand variability following Randall et al. (2006), there are alternative procedures to calculate variability.

We conducted unreported (available upon request from authors) tests to include the quadratic effects of demand variabilities on inventory performance improvements after a merger. In the first and second years following the merger, the inclusion of the quadratic effect results in either decreased or the same adjusted $R^{2}$. The adjusted $R^{2}$ increases at a noticeable amount only in the third year following the merger, in which first-degree effects remain the same and the second-degree effect of the target variability proves to be significant. However, the results are still not significant enough to make a strong judgment on the first or second-degree effects of demand variabilities on inventory pooling benefits.

This study is one of the very first attempts to test the predictions of inventory centralization theory using real data. Follow-up studies may improve the findings in three directions. First, as we do not have information on the individual policy changes that are enacted following a merger, we cannot forcefully say the results are due to a strategic change in inventory management. Follow-up studies may undertake case studies and analyze whether the merged firms with negative demand correlation in the sample did centralize inventory decisions (Hendricks and Singhal, 2009).

Second, inventory management models in the literature are at product level. However, we only have access to firm-level inventory data from COMPUSTAT. Firm-level inventory data is reported for all products of the firm aggregated as raw materials, work-in-process, finished goods, and their total. In this study, we used total inventory, as the data on raw materials, work-in-process, and finished goods have many missing company-year entries, which prevent us to compute demand variability and demand correlation. Thus, with secondary sources such as COMPUSTAT, it is difficult to obtain product-level data. Data on product-level inventories of merging firms would offer more detailed analysis of the theoretical models on inventory management.

Third, alternative measurements of inventory performance may be used. One alternative is the inventory turnover curve method proposed by Ballou (1981). Ballou (1981) and Ballou (2000) use sales and absolute inventory level data of various stocking points for similar products to define the relationship between sales and inventory. A turnover curve can be used to evaluate the inventory performance of merging firms. Eroglu and Hofer (2011) investigate the relationship between the financial performance and the inventory leanness of U.S. manufacturing firms, where the inventory leanness is calculated with the deviation of a firm's inventory level from the turnover curve fitted for its industry.

\section{Acknowledgments}

Başak Tanyeri gratefully acknowledges the research support of TUBITAKGrant 110K330.

\section{References}

Alptekinoglu, A., Tang, C.S., 2005. A model for analyzing multi-channel distribution systems. Eur. J. Oper. Res. 163 (3), 802-824.

Ambrose, B.W., Megginson, W.L., 1992. The role of asset structure, ownership structure, and takeover defenses in determining acquisition likelihood. J. Finan. Quant. Anal. 27, 575-589.

Andrade, G., Mitchell, M., Stafford, E., 2001. New evidence and perspectives on mergers. J. Econ. Perspect. 15, 103-120.
Aydin, B, Guler, K., Kayis, E., 2012. A copula approach to inventory pooling problems with newsvendor products. In: Choi, T.-M. (Ed.), Handbook of Newsvendor Problems. Springer, New York, NY, pp. 81-101.

Baker, K.R., Magazine, M.J., Nuttle, H.L.M., 1986. The effect of commonality on safety stock in a simple inventory model. Manage. Sci. 32 (8), 982-988.

Ballou, R.H., 1981. Estimating and auditing aggregate inventory levels at multiple stocking points. J. Oper. Manage. 1 (3), 143-153.

Ballou, R.H., 2000. Evaluating inventory management performance using a turnover curve. Int. J. Phys. Distrib. Logist. Manage. 30 (1), 72-85.

Ben-Zvi, N., Gerchak, Y., 2012. Inventory centralization in a newsvendor setting when shortage costs differ: priorities and costs allocation. In: Choi, T.-M. (Ed.) Handbook of Newsvendor Problems, Springer, New York, NY, pp. 263-276.

Benjaafar, S., Cooper, W.L., Kim, J.-S., 2005. On the benefits of pooling in production-inventory systems. Manage. Sci. 51 (4), 548-565.

Berman, O., Krass, D., Tajbakhsh, M.M., 2011. On the benefits of risk pooling in inventory management. Prod. Oper. Manage. 20 (1), 57-71.

Bernile,G., Bauguess,S.W.2010. Do Merger Synergies Exist? Available at SSRN: $\langle$ http://ssrn.com////abstract=642322.

Betton, S., Eckbo, B.E., Thorburn, K.S., 2008. Corporate takeovers. In: Eckbo, E. (Ed.), Handbook of Corporate Finance, vol. 2. Elsevier, pp. 291-430.

Bish, E.K., Suwandechochai, R., 2010. Optimal capacity for substitutable products under operational postponement. Eur. J. Oper. Res. 207 (2), 775-783.

Bogan, V., Just, D., 2009. What drives merger decision making behavior? Don't seek don't find, and don't change your mind. J. Econ. Behav. Organ. 72, 930-943.

Bouma, H.W., Teunter, R.H., 2014. The routed inventory pooling problem with three non-identical retailers. Int. J. Prod. Econ. 156, 223-234.

Bowman, R.J., 2003. In a marriage of giants, HP and Compaq successfully merge supply chains. Global Logist. Supply Chain Strategies 7 (6), 38-41.

Bruner, R.F., 2004. Applied Mergers \& Acquisitions. Wiley, Hoboken, NJ.

Cachon, G.P., Randall, T., Schmidt, G.M., 2007. In search of the bullwhip effect Manuf. Serv. Oper. Manage. 9 (4), 457-479.

Cai, X., Du, D., 2009. On the effects of risk pooling in supply chain management: review and extensions. Acta Math. Appl. Sin. 25 (4), 709-722.

Chen, H., Frank, M.Z., Wu, O.Q., 2005. What actually happened to the inventories of American Companies between 1981 and 2000? Manage. Sci. 51 (7), 1015-1031.

Chen, H., Frank, M.Z., Wu, O.Q., 2007. U.S. retail and wholesale inventory performance from 1981 to 2004. Manuf. Serv. Oper. Manage. 9 (4), 430-456.

Chen, M.-S., Lin, C.-T., 1990. An example of disbenefits of centralized stocking. Oper. Res. Soc. 41 (3), 259-262.

Corbett, C.J., Rajaram, K., 2006. A generalization of the inventory pooling effect to nonnormal dependent demand. Manuf. Serv. Oper. Manage. 8 (4), 351-358.

Cornett, M.M., Tanyeri, B., Tehranian, H., 2011. The effect of merger anticipation on bidder and target firm announcement period returns. J. Corp. Finan. 173, 595-611.

Çömez, N., Stecke, K.E., Çakanyildirim, M., 2012. Multiple in-cycle transshipments with positive delivery times. Prod. Oper. Manage. 21 (2), 378-395.

Cremers, K.J.M., Nair, V.B., John, K., 2009. Takeovers and cross-section of returns. Rev, Finan. Stud, 22, 1409-1445.

Davila, T., Wouters, M., 2007. An empirical test of inventory, service and cost benefits from a postponement strategy. Int. J. Prod. Res. 45 (10), 2245-2267.

Eppen, G.D., 1979. Effects of centralization on expected costs in a multi-location newsboy problem. Manage. Sci. 25 (5), 498-501.

Eroglu, C., Hofer, C., 2011. Lean, leaner, too lean? The inventory-performance link revisited. J. Oper. Manage. 29, 356-369.

Fescioglu-Unver, N., Tanyeri, B., 2013. A comparison of artificial neural network and multinomial logit models in predicting mergers. J. Appl. Stat. 40 (4), 712-720.

Fluck, Z., Lynch, A.W., 1999. Why do firms merge and then divest? A theory of financial synergy. J. Bus. 72, 319-346.

Gaur, V., Fisher, M.L., Raman, A., 2005. An econometric analysis of inventory turnover performance in retail services. Manage. Sci. 51 (2), 181-194.

Gerchak, Y., Mossman, D., 1992. On the effect of demand randomness on inventories and costs. Oper. Res. 40 (4), 804-807.

Gerchak, Y., He, Q.M., 2003. On the relation between the benefits of risk pooling and the variability of demand. IIE Trans. 35, 1027-1031.

Gort, M., 1969. An economic disturbance theory of mergers. O. J. Econ. 83, 624-642.

Grahovac, J., Chakravarty, A., 2001. Sharing and lateral transshipment of inventory in a supply chain with expensive low-demand items. Manage. Sci. 47 (4) 579-594.

Grinstein, Y., Hribar, P., 2004. CEO compensation and incentives: evidence from M\&A bonuses. J. Finan. Econ. 731, 119-143.

Gugler, K., Mueller., D.C., Yurtoglu, B.B., Zulehner, C., 2003. The effects of mergers: an international comparison. Int. J. Ind. Organ. 21, 625-653.

Gupta, D., Gerchak, Y., 2002. Quantifying operational synergies in a merger acquisition. Manage. Sci. 48 (4), 517-533.

Günes, E.D., Yaman, H., 2010. Health network mergers and hospital re-planning. J. Oper. Res. Soc. 61 (2), 275-283.

Harris, F.W., 1913. How many parts to make at once. Factory, Mag. Manage. 10 (2), 135-136.

Harris II, J., Ozgen, H., Ozcan, Y., 2000. Do mergers enhance the performance of hospital efficiency? J. Oper. Res. Soc. 51, 801-811.

Hartzell, J., Ofek, E., Yermack, D., 2004. Whats in it for me? CEOs whose firms are acquired. Rev. Finan. Stud. 17, 37-61.

Hendricks, K.B., Singhal, V.R., 2009. Demand-supply mismatches and stock market reaction: evidence from excess inventory announcements. Manuf. Serv. Oper. Manage. 11 (3), 509-524. 
Hillier, M.S., 2000. Component commonality in multiple-period, assemble-to-order systems. IIE Trans. 32, 755-766.

Hillier, M.S., 2002. The costs and benefits of commonality in assemble-to-order systems with a (Qr)-policy for component replenishment. Eur. J. Oper. Res. 141 (3), 570-586.

Holmes, T.J., Schmitz, J.A., 1995. On the turnover of business firms and business managers. Eur. J. Polit. 103, 1005-1038.

Iyer, A.V., Jain, A., 2004. Modeling the impact of merging capacity in productioninventory systems. Manage. Sci. 50 (8), 1082-1094.

Jarrell, G.A., Brickley, J.A., Netter, J.M., 1988. The market for corporate control: the scientific evidence since 1980. J. Econ. Perspect. 2, 49-68.

Jensen, M.C., 1986. Agency costs of free cash flow, corporate finance and takeovers Am. Econ. Rev. 76, 323-339.

Jovanovic, B., Rousseau, P., 2002. The Q-theory of mergers. Am. Econ. Rev. 92, 198-204.

Kroger. 1998. Press Releases. 〈http://www.thekrogerco.com/corpnews/corpnewsin fopressreleases10191998.htm $\rangle$.

Lang, L.H.P., Stulz, R.M., Walkling, R.A., 1989. Managerial performance, Tobin's q and the gains from successful tender offers. J. Finan. Econ. 24, 137-154.

Langabeer, J., 2003. An investigation of post-merger supply chain performance. J. Acad. Bus. Econ. 2 (1), 14-25.

Louis, H., 2004. Earnings management and the market performance of acquiring firms. J. Finan. Econ. 74, 121-148.

Maksimovic, V., Phillips, G., 2001. The market for corporate assets: who engages in mergers and asset sales and are there efficiency gains? J. Finance 56, 2019-2065.

Martynova, M., Renneboog, L., 2008. A century of corporate takeovers: what have we learned and where do we stand? J. Banking Finance 32 (10), 2148-2177.

Mitchell, M.L., Mulherin, H.J., 1996. The impact of industry shocks on takeover and restructuring activity. J. Finan. Econ. 41, 193-229.
Moeller, S.B., Schlingenmann, F., Stulz, R.M., 2004. Firm size and the gains from acquisitions. J. Finan. Econ. 73, 201-228.

Ngniatedema, T., Shanker, M., Hu, M.Y., Guiffrida, A.L., Patuwo, B.E., 2015. Late customization strategy with service levels requirements. Int. J. Prod. Econ. 166, $72-84$.

Rajagopalan, S., Malhotra, A., 2001. Have U.S. manufacturing inventories really decreased? An empirical study. Manuf. Serv. Oper. Manage. 3 (1), 14-24.

Randall, T., Netessine, S., Rudi, N., 2006. An empirical examination of the decision to invest in fulfillment capabilities: a study of internet retailers. Manage. Sci. 52 (4), 567-580.

Roll, R., 1986. The hubris hypothesis of corporate takeovers. J. Bus. 59, 197-216.

Rumyantsev, S., Netessine, S., 2007. What can be learned from classical inventory models? A cross-industry exploratory investigation. Manuf. Serv. Oper. Manage. 9 (4), 409-429.

Satır, B., Savasaneril, S., Serin, Y., 2012. Pooling through lateral transshipments in service parts systems. Eur. J. Oper. Res. 220 (2), 370-377.

Stulman, A., 1987. Benefits of centralized stocking for the multi-centre newsboy problem with first come, first served allocation. J. Oper. Res. Soc. 38 (9), 827-832.

Tai, A.H., Ching, W.-K., 2014. Optimal inventory policy for a Markovian two-echelon system with returns and lateral transshipment. Int. J. Prod. Econ. 151, 48-55.

Tibben-Lembke, R.S., Bassok, Y., 2005. An inventory model for delayed customization: a hybrid approach. Eur. J. Oper. Res. 165 (3), 748-764.

U.S. Department of Justice and Federal Trade Commission. 2006. Commentary on the Horizontal Merger Guidelines. 〈http://www.justice.gov/atr/public/guide lines/215247.pdf).

Yang, H., Schrage, L., 2009. Conditions that cause risk pooling to increase inventory. Eur. J. Oper. Res. 192, 837-851.

Ye, T., 2014. Inventory management with simultaneously horizontal and vertical substitution. Int. J. Prod. Econ. 156, 316-324. 